\title{
Serum Cystatin C as a Biomarker for Predicting Coronary Artery Disease in Diabetes
}

\author{
Jee-Young Oh \\ Department of Internal Medicine, Ewha Womans University Mokdong Hospital, Ewha Womans University School of Medicine, Seoul, Korea
}

Cardiovascular (CV) disease, including coronary artery disease (CAD) is the leading cause of death in adults with type 2 diabetes [1], because accompanied other risk factors such as dyslipidemia, hypertension, prothrombic and proinflammatory factors each contribute to accelerated atherosclerosis in obese type 2 diabetes mellitus [2]. Still, the pathophysiologic mechanisms accounting for a substantially increased risk for CAD in adult type 2 diabetes remain unclear. A great efforts for discovery and validation of the novel risk factors in order to potentially identify high-risk individuals that may benefit from aggressive preventive strategies have been performed nowadays.

It has been extensively demonstrated that inflammation plays a pivotal role in atherosclerosis, and that inflammatory markers such as C-reactive protein (CRP), fibrinogen, metallic metalloproteinase-9 (MMP-9), lipoprotein-associated phospholipase A2 (Lp-PLA2), interleukin-6 (IL-6), tumor necrosis factor $\alpha$ (TNF- $\alpha$ ) and beta-fibroblast growth factor (bFGF), may aid in the detection of individuals at higher CV risk [3-5]. In almost all the studies, the association between inflammatory markers and coronary atherosclerosis was weak and mostly explained by concomitant burden of CAD risk factors. Although measurements of these inflammatory markers have been immense promise as predictive markers for future CAD, currently there is lack of strong evidence that it adds significantly to global risk assessment [6].

Various adipocytokines, such as leptin, adiponectin, resistin, and retinol-binding protein 4 (RBP-4) have been reported to associate the obesity, insulin resistance, and finally CV events [710]. Circulating levels of these cytokines can be used as high- throughput biomarkers to assess the obesity-related health problems, including low grade inflammation.

Cystatin $\mathrm{C}$ is a novel endogenous marker of kidney function that may be more sensitive for detecting mild to moderate decrements in glomerular filtration rate [11]. Cystatin C is superior to serum creatinine or creatinine-based estimating equations for prediction of all-cause mortality, CV events, and incident congestive heart failure in elderly community-based cohorts [12-15]. The Framingham Offspring prospective cohort study showed the independent association with CV risk factors such as age, female sex, BMI, low high density lipoprotein cholesterol (HDL-C), and smoking in 3,241 participants [14]. Third National Health and Nutrition Examination Survey participants were subvidived according to cystatin C quartiles, and the prevalence of CVD myocardial infarction, agina pectoris, and stroke increased with increasing concentrations of cystatin $\mathrm{C}$, and after adjustment for age, sex, race, and principal CV risk factors, cystatin C was independently associated with CVD [15]. Concomitant chronic kidney disease predicts CV events as strongly as other established risk factors [16], and low urinary creatinine excretion rate has been suggested as a modifiable risk factor for mortality among persons with CAD [17]. However, 10 year follow-up study in a community-based population of elderly subjects found no evidence that cystatin C was a better risk prediction than creatinine or creatinine clearance, suggesting further investigation should be required [18].

Kim et al. [19] reported in this issue that there was no association between serum cystatin $\mathrm{C}$ level and CAD in diabetic patients. They found the serum cystatin $\mathrm{C}$ levels was signifi-
Corresponding author: Jee-Young Oh

Department of Internal Medicine, Ewha Womans University Mokdong

Hospital, 911-1 Mok-dong, Yangcheon-gu, Seoul 158-710, Korea

E-mail: jyoh@ewha.ac.kr
This is an Open Access article distributed under the terms of the Creative Commons Attribution Non-Commercial License (http://creativecommons.org/licenses/by-nc/3.0/) which permits unrestricted non-commercial use, distribution, and reproduction in any medium, provided the original work is properly cited. 
cantly higher in patients with diabetic nephropathy, both in CAD patients and non-CAD patients.

Recent studies have been suggesting complementary prognostic value of multiple biomarkers approach to improve prediction of CV risk. Approach with multiple inflammatory markers might be of interest since different inflammatory markers may enhance or initiate different and not always overlapping inflammatory pathways leading to atherosclerosis and cardiac events and lay indicate different stage of atherosclerosis.

Several non-invasive markers of subclinical such as flowmediated dilatation in the brachial artery, carotid intima-medial thickness, and pulse wave velocity have been associated with significant, but not always strong relationships with both traditional risk factors of CVD and inflammatory markers.

In conclusion, it is possible that a multimarker approach using a combination of these non-invasive test as well as various biomarkers including serum cystiatin $\mathrm{C}$ would also be useful in clinical practice, since each test is related only weakly with each other, and reflect different aspects of the atherosclerotic process.

\section{REFERENCES}

1. American Diabetes Association. Standards of medical care in diabetes: 2010. Diabetes Care 2010;33 Suppl 1:S11-61.

2. Folsom AR, Chambless LE, Duncan BB, Gilbert AC, Pankow JS. Prediction of coronary heart disease in middle-aged adults with diabetes. Diabetes Care 2003;26:2777-84.

3. Ross R. Atherosclerosis: an inflammatory disease. N Engl J Med 1999;340:115-26.

4. Cohn JN, Quyyumi AA, Hollenberg NK, Jamerson KA. Surrogate markers for cardiovascular disease: functional markers. Circulation 2004;109:IV31-46.

5. Mancini GB, Dahlof B, Diez J. Surrogate markers for cardiovascular disease: structural markers. Circulation 2004;109: IV22-30.

6. Ikonomidis I, Stamatelopoulos K, Lekakis J, Vamvakou GD, Kremastinos DT. Inflammatory and non-invasive vascular markers: the multimarker approach for risk stratification in coronary artery disease. Atherosclerosis 2008;199:3-11.

7. Sattar N, Wannamethee G, Sarwar N, Chernova J, Lawlor DA, Kelly A, Wallace AM, Danesh J, Whincup PH. Leptin and coronary heart disease: prospective study and systematic review. J Am Coll Cardiol 2009;53:167-75.

8. Antoniades C, Antonopoulos AS, Tousoulis D, Stefanadis C.
Adiponectin: from obesity to cardiovascular disease. Obes Rev 2009;10:269-79.

9. Reilly MP, Lehrke M, Wolfe ML, Rohatgi A, Lazar MA, Rader DJ. Resistin is an inflammatory marker of atherosclerosis in humans. Circulation 2005;111:932-9.

10. von Eynatten M, Lepper PM, Liu D, Lang K, Baumann M, Nawroth PP, Bierhaus A, Dugi KA, Heemann U, Allolio B, Humpert PM. Retinol-binding protein 4 is associated with components of the metabolic syndrome, but not with insulin resistance, in men with type 2 diabetes or coronary artery disease. Diabetologia 2007;50:1930-7.

11. Fliser D, Ritz E. Serum cystatin C concentration as a marker of renal dysfunction in the elderly. Am J Kidney Dis 2001;37:79-83.

12. Shlipak MG, Sarnak MJ, Katz R, Fried LF, Seliger SL, Newman AB, Siscovick DS, Stehman-Breen C. Cystatin C and the risk of death and cardiovascular events among elderly persons. $\mathrm{N}$ Engl J Med 2005;352:2049-60.

13. Sarnak MJ, Katz R, Stehman-Breen CO, Fried LF, Jenny NS, Psaty BM, Newman AB, Siscovick D, Shlipak MG. Cystatin C concentration as a risk factor for heart failure in older adults. Ann Intern Med 2005;142:497-505.

14. Parikh NI, Hwang SJ, Yang Q, Larson MG, Guo CY, Robins SJ, Sutherland P, Benjamin EJ, Levy D, Fox CS. Clinical correlates and heritability of cystatin C (from the Framingham Offspring Study). Am J Cardiol 2008;102:1194-8.

15. Muntner P, Mann D, Winston J, Bansilal S, Farkouh ME. Serum cystatin $\mathrm{C}$ and increased coronary heart disease prevalence in US adults without chronic kidney disease. Am J Cardiol 2008;102:54-7.

16. Shlipak MG, Simon JA, Grady D, Lin F, Wenger NK, Furberg $\mathrm{CD}$. Renal insufficiency and cardiovascular events in postmenopausal women with coronary heart disease. J Am Coll Cardiol 2001;38:705-11.

17. Ix JH, de Boer IH, Wassel CL, Criqui MH, Shlipak MG, Whooley MA. Urinary creatinine excretion rate and mortality in persons with coronary artery disease: the Heart and Soul Study. Circulation 2010;121:1295-303.

18. Beilby J, Divitini ML, Knuiman MW, Rossi E, Hung J. Comparison of cystatin $\mathrm{C}$ and creatinine as predictors of cardiovascular events in a community-based elderly population. Clin Chem. Forthcoming 2010.

19. Kim EH, Yu JH, Lee SA, Kim EY, Kim WG, Lee SH, Cho EH, Koh EH, Lee WJ, Kim MS, Park JY, Lee KU. Lack of association between serum cystatin $\mathrm{C}$ levels and coronary artery disease in diabetic patients. Korean Diabetes J 2010;34:95-100. 